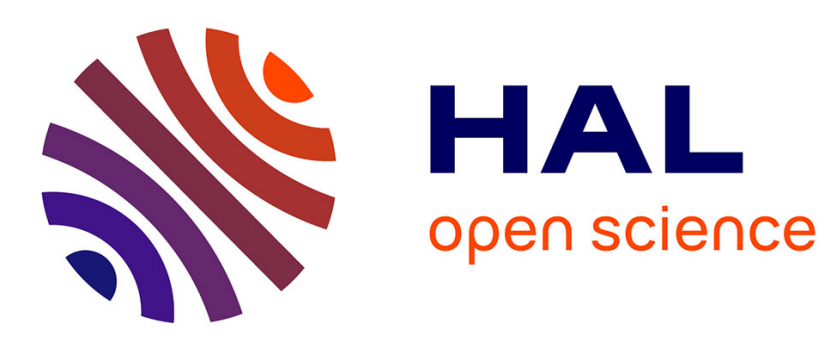

\title{
Comparative Study of Zeolite L Etching with Ammonium Fluoride and Ammonium Bifluoride Solutions
}

Viktoria Babić, Lingxue Tang, Zhengxing Qin, Leila Hafiz, Jean-pierre Gilson, Valentin Valtchev

\section{To cite this version:}

Viktoria Babić, Lingxue Tang, Zhengxing Qin, Leila Hafiz, Jean-pierre Gilson, et al.. Comparative Study of Zeolite L Etching with Ammonium Fluoride and Ammonium Bifluoride Solutions. Advanced Materials Interfaces, inPress, pp.2000348. 10.1002/admi.202000348 . hal-02881934

\section{HAL Id: hal-02881934 https://hal.science/hal-02881934}

Submitted on 2 Dec 2020

HAL is a multi-disciplinary open access archive for the deposit and dissemination of scientific research documents, whether they are published or not. The documents may come from teaching and research institutions in France or abroad, or from public or private research centers.
L'archive ouverte pluridisciplinaire HAL, est destinée au dépôt et à la diffusion de documents scientifiques de niveau recherche, publiés ou non, émanant des établissements d'enseignement et de recherche français ou étrangers, des laboratoires publics ou privés. 
WILEY-VCH

Comparative Study of Zeolite L Etching with Ammonium Fluoride and Ammonium Bifluoride Solutions

Viktoria Babić, Lingxue Tang, Zhengxing Qin, Leila Hafiz, Jean-Pierre Gilson, Valentin Valtchev*

V. Babić, Dr. L. Hafiz, Prof. J.-P. Gilson, Dr. V. Valtchev

Normandie Univ, ENSICAEN, UNICAEN, CNRS, Laboratoire Catalyse et Spectrochimie, 14000

Caen, France

E-mail: valentin.valtchev@ensicaen.fr

Dr. L. Tang

State Key Laboratory of Inorganic Synthesis and Preparative Chemistry, Jilin University, Changchun 130012, China

Dr. Z. Qin

College of Chemical Engineering, China University of Petroleum, Qingdao 266580, China

Keywords: zeolite L, mesopores, hierarchical, fluoride etching

A commercial zeolite $\mathrm{L}$ was subjected to chemical etching with aqueous solutions of $\mathrm{NH}_{4} \mathrm{~F}$ and $\mathrm{NH}_{4} \mathrm{HF}_{2}$ to generate secondary porosity. The derived samples were characterized by X-ray diffraction, $\mathrm{N}_{2}$ adsorption, scanning and transmission electron microscopy, ${ }^{27} \mathrm{Al}$ MAS NMR, thermogravimetric analysis, and their acid sites were quantified by FTIR spectroscopy of adsorbed basic probe molecules. The catalytic properties of the pristine and modified zeolites were evaluated in the dealkylation of 1,3,5-triisopropylbenzene. Tuning the etching conditions allowed us to generate hierarchical zeolites without losing micropore volume. Furthermore, both fluoride etchants did not change the acid properties of the zeolite substantially, which is confirmed by chemical composition anlysis (ICP-AES) and by FTIR spectroscopy of pyridine. The dissolution rate of zeolite $\mathrm{L}$ was much faster with $\mathrm{NH}_{4} \mathrm{HF}_{2}$ than $\mathrm{NH}_{4} \mathrm{~F}$. The set of experimental data shows that the 1 wt $\% \mathrm{NH}_{4} \mathrm{HF}_{2}$ solution is an efficient etchant able to generate mesopores without affecting the parent zeolite properties as lower amounts of fluoride source are required than with concentrated $(20-40 \mathrm{wt} \%) \mathrm{NH}_{4} \mathrm{~F}$ solutions. 


\section{WILEY-VCH}

\section{Introduction}

Zeolites are widely used in the chemical industry as catalysts, molecular sieves, sorbents, and ionexchange materials. ${ }^{[1]}$ Their catalytic properties are unique as their acid sites (Brønsted and Lewis) are located in confined space, providing shape selectivity during hydrocarbon conversions. Zeolite L (LTL-type) was first synthesized by Breck and Acara and its framework topology determined by Baerlocher and Barrer. ${ }^{[2]}$ It possesses a one-dimensional pore structure, its framework consists of cancrinite cages linked with hexagonal prisms to form columns in the cdirection; they in turn, form pores with an internal diameter of $1.2 \mathrm{~nm}$ and 12 -member ring (MR) pore opening windows with a diameter of $0.71 \mathrm{~nm} \cdot{ }^{[3]}$ Zeolite $\mathrm{L}$ is typically synthesized with $\mathrm{Si} / \mathrm{Al}=$ 3 using $\mathrm{K}^{+}$as a structure directing agent.

Zeolite L loaded with noble metals is an excellent catalyst for the low pressure aromatization (dehydrocyclization) of paraffins $\left(\mathrm{C}_{6-8}\right)$ in light naphtha; such paraffins are poorly converted on classical platinum reforming catalysts $\left(\mathrm{Pt} / \mathrm{Al}_{2} \mathrm{O}_{3}-\mathrm{Cl}\right) \cdot{ }^{[4]}$ However, due to the operating conditions of this reforming reaction (high temperature, low pressure), the catalyst suffers from deactivation by coke deposition; ${ }^{[5-7]}$ the known remedy is to operate in a dual catalyst bed process, the so-called CCR (Continuous Catalyst Regeneration) pioneered by UOP. ${ }^{[8]}$ Zeolite L is also claimed as active in catalytic cracking ${ }^{[9,10]}$ and a hierarchical derivative in FCC gasoline hydrodesulphurization. ${ }^{[11,12]}$ A key disadvantage of zeolite $\mathrm{L}$ is its monodimensional pore system, especially when bulky molecules are converted. For full range naphthas, diffusion is hindered and penalizes the activity, selectivity, and stability of the derived catalyst. ${ }^{[5,11]}$ Active sites accessible for bulky molecules are available at the pore mouth and zeolite crystal surface, but they represent less than $5 \%$ of the total active sites. $^{[13]}$

Two strategies are commonly used to reduce the impact of diffusion limitations in zeolites: $i$ ) decrease of the crystal size $\left.{ }^{[14]}, i i\right)$ introduction of larger (meso- or macro) pores in the crystals. ${ }^{[15]}$ 


\section{WILEY-VCH}

Nanozeolites $(<100 \mathrm{~nm}$ crystal size) have relatively high external surface area and the portion of active sites available on the external surface is higher than that of micro-sized crystals. However, the number of zeolites that can be synthesized in nanosized form is still limited. ${ }^{[13,15,16]}$ Consequently, much research is devoted to the preparation of zeolite crystals comprising larger secondary pores. The methods to introduce secondary pores can be classified into two groups, bottom-up and top-down approaches. Constructive or bottom-up methods are synthetically challenging and build hierarchical zeolites through the engineering of microporous and mesoporous domains utilizing complicated templating routes. ${ }^{[17,18]}$ While there are some reports of using commercially available and inexpensive OSDA, ${ }^{[19]}$ direct synthesis of mesoporous zeolite $\mathrm{L}$ is extremely scarce. ${ }^{[12]}$ Top-down approaches are more reproducible and favored for commercial production of hierarchical zeolites. ${ }^{[20]}$

Destructive or top-down methods include a variety of techniques to introduce a secondary level of porosity in as-synthesized zeolites through post-synthesis modification. Post-synthesis treatments are used to modify and improve the zeolite properties that cannot be achieved through direct synthesis. These treatments include steaming and etching with various, acid or base, solutions that cause dealumination and/or desilication while generating secondary pores. ${ }^{[16,18]}$

Etching with buffered solutions of $\mathrm{HF} / \mathrm{NH}_{4} \mathrm{~F}$ was shown earlier to yield hierarchical zeolites with retained chemical composition, due to the formation of $\mathrm{HF}_{2}{ }^{-}$anions affording an unbiased extraction of $\mathrm{Si}$ and $\mathrm{Al} .{ }^{[21,22]}$ Besides avoiding the use of $\mathrm{HF}, \mathrm{NH}_{4} \mathrm{~F}$ generates a steady source of small quantities of $\mathrm{HF}_{2}{ }^{-}$allowing easy control of the dissolution kinetics. However, the $\mathrm{NH}_{4} \mathrm{~F}$ route is based on the use of relatively concentrated $\left(20-40 \mathrm{wt} . \% \mathrm{NH}_{4} \mathrm{~F}\right)$ solutions.

$\mathrm{NH}_{4} \mathrm{HF}_{2}$ was proposed as a benign etching solution to clean silicon dioxide from semiconductor wafer surfaces. ${ }^{[23]}$ Feng et al. showed that an $\mathrm{NH}_{4} \mathrm{HF}_{2}$ solution effectively removes non-framework aluminum and silicon from a $\mathrm{NaY}$ zeolite. However, the zeolite etching with $\mathrm{NH}_{4} \mathrm{HF}_{2}$ is still unexplored territory and not much information on the particularities of zeolite dissolution is

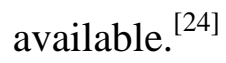




\section{WILEY-VCH}

The objective of this work is to compare the etching ability of $\mathrm{NH}_{4} \mathrm{~F}$ and $\mathrm{NH}_{4} \mathrm{HF}_{2}$ to obtain hierarchical zeolite L crystals. This study focuses on the physicochemical properties of the parent L and its hierarchical derivatives obtained with $\mathrm{NH}_{4} \mathrm{~F}$ and $\mathrm{NH}_{4} \mathrm{HF}_{2}$, as well as their catalytic performance in the conversion of a bulky molecule.

\section{Results}

The $\mathrm{NH}_{4}$-form of zeolite $\mathrm{L}$ was subjected to fluoride etching. The codes used to denote different samples are provided in the experimental section. Briefly, the samples treated at $25^{\circ} \mathrm{C}$ were denoted L-I-x, where $\mathrm{x}$ is the treatment time. The samples treated at $60 / 80^{\circ} \mathrm{C}$ are denoted $\mathrm{L}-\mathrm{II}-\mathrm{x}-60 / 80$, where $\mathrm{x}$ is the treatment time. The XRD analysis reveals that the treatment at $25{ }^{\circ} \mathrm{C}$ with $\mathrm{NH}_{4} \mathrm{~F}$ and $\mathrm{NH}_{4} \mathrm{HF}_{2}$, does not lead to structural changes (100\% crystallinity), whatever the fluoride concentrations. The treatment with a $20 \mathrm{wt} \% \mathrm{NH}_{4} \mathrm{~F}$ solution was extended up to 480 min without visible changes in the XRD crystallinity (Figure 1). The effect of 40 wt $\% \mathrm{NH}_{4} \mathrm{~F}$ on the zeolite crystallinity was studied up to 90 min and no change in the crystallinity was observed (Figure S1). Our preliminary experiments indicated that an $\mathrm{NH}_{4} \mathrm{HF}_{2}$ solution is more aggressive and requires the use of much more dilute solutions with respect to $\mathrm{NH}_{4} \mathrm{~F}$. For instance, a 1 wt $\% \mathrm{NH}_{4} \mathrm{HF}_{2}$ (L-III-x) solution was used in order to retain the zeolite L crystallinity (Figure S2).

The $\mathrm{NH}_{4} \mathrm{~F}$ treatment at elevated temperatures $\left(60\right.$ and $\left.80{ }^{\circ} \mathrm{C}\right)$ had a more pronounced effect on zeolite L crystallinity. For instance, L-I-60-80 and L-II-60-80 exhibited 43\% and 18\% crystallinity, respectively, with respect to the parent zeolite. In addition, the patterns display a broad feature 15$30^{\circ} 2 \theta$, indicating amorphization, proof that under such conditions, a substantial dissolution of the zeolite framework takes place. A decrease in crystallinity is also observed for the samples treated at $60{ }^{\circ} \mathrm{C}$. Thus, L-I-60-60 and L-II-60-60 samples showed a crystallinity of $79 \%$ and $78 \%$, respectively. Samples treated with 1 wt $\% \mathrm{NH}_{4} \mathrm{HF}_{2}$ at 60 and $80^{\circ} \mathrm{C}$ also exhibited some loss of crystallinity, which was $91 \%$ and $89 \%$ for L-III-60-60 and L-III-60-80, respectively. 


\section{WILEY-VCH}

On the other hand, the treatment with $1 \mathrm{wt} \% \mathrm{NH}_{4} \mathrm{HF}_{2}$ at room temperature and up to 120 min leads to materials with increased XRD crystallinity. A slight decrease in the crystallinity is observed for the sample etched 180 minutes. Room temperature treatment of zeolite $\mathrm{L}$ with a $2 \mathrm{wt} \% \mathrm{NH}_{4} \mathrm{HF}_{2}$ for 10 min (L-IV-10) also yields materials with higher relative crystallinity (Table 1, Figure S3). We attribute this increase in crystallinity to the dissolution of some amorphous material present on the sample and low crystalline part of the crystals, all typical for such unbiased framework etching. ${ }^{[21]}$ The impact of fluoride etching on the morphology of zeolite L is studied with a scanning electron microscope (Figure 2). Typically, zeolite L exhibits a disc like morphology with overgrown terraces on the pinacoidal face. Steps are also observed on the prismatic face but they are not so pronounced as on the basal pinacoid. This etching yields crystals with cracks and holes going deeply in the pinacoidal surface, while the sharp edges of the prismatic surface disappear, smoothing out the surface.

Transmission electron microscope (TEM) sheds more light on the most deeply etched samples and highlights details of the remaining part of the crystal (Figure 3). Entire crystalline domains are clearly separated from the parent crystal. TEM micrographs of the parent L zeolite and its etched derivatives are depicted in Figure 3A-F. The surface of the parent and the $\mathrm{NH}_{4} \mathrm{~F}$ treated zeolites (Figure 3A-C) appear smooth, while those treated with $\mathrm{NH}_{4} \mathrm{HF}_{2}$ display rougher surfaces. Figure 3F highlights dissolution on the edges of the crystals, and Figure 3D-E show extended dissolution along the crystal surface with visible formation of mesopores.

The textural properties of the parent zeolite and treated samples are assessed by nitrogen physisorption (Figure S4). $\mathrm{N}_{2}$ isotherms of the parent zeolite and the derivatives treated with 20 wt $\% \mathrm{NH}_{4} \mathrm{~F}$ solution at room temperature exhibit a type Ia isotherm according to the IUPAC classification. However, the fast uptake at low relative pressure characteristic of microporous materials is followed by an inclination of the isotherm, terminating with an H4 hysteresis loop in the high relative pressure region $(\sim 0.98)$. The latter is characteristic of the presence of textural mesopores. The surface and pore features of the derivatives produced by fluoride treatments are 


\section{WILEY-VCH}

summarized in Table 1. The mesopore volume increases slightly with treatment time when 20 wt \% $\mathrm{NH}_{4} \mathrm{~F}$ is used. The micropore volume remains almost constant $\left(0.17 \mathrm{~cm}^{3} / \mathrm{g}\right)$ up to $240 \mathrm{~min}$ and then decreases to $0.16 \mathrm{~cm}^{3} \mathrm{~g}^{-1}$ after 360 - and 480 -min treatment. A more substantial decrease occurs after treatment at $60{ }^{\circ} \mathrm{C}\left(0.14 \mathrm{~cm}^{3} \mathrm{~g}^{-1}\right)$ and $80{ }^{\circ} \mathrm{C}\left(0.08 \mathrm{~cm}^{3} \mathrm{~g}^{-1}\right)$. At elevated temperatures $\left(60\right.$ and $\left.80{ }^{\circ} \mathrm{C}\right)$, the mesopore volume is substantially increased up to $0.20 \mathrm{~cm}^{3} \mathrm{~g}^{-1}$, while the micropore volume drops further to $0.08 \mathrm{~cm}^{3} \mathrm{~g}^{-1}$ (Table 1).

The use of a more concentrated $\left(40 \mathrm{wt} \% \mathrm{NH}_{4} \mathrm{~F}\right)$ solution results in a faster dissolution of zeolite $\mathrm{L}$. The samples are treated only up to 90 minutes as after 20 min only the mesopore volume increases from 0.05 to $0.13 \mathrm{~cm}^{3} \mathrm{~g}^{-1}$. Any further increase in the treatment time does not increase mesopore volume. The micropore volume and the crystallinity of all room temperature treated samples are retained. The sample treated at $60{ }^{\circ} \mathrm{C}$ shows a small loss of micropore volume and a substantial increase of mesopore volume. The most dramatic changes, a severe loss of crystallinity and micropore volume, are observed in the sample treated at $80{ }^{\circ} \mathrm{C}$. As mentioned, the preliminary experiments with 20 and 40 wt $\% \mathrm{NH}_{4} \mathrm{HF}_{2}$ solutions resulted in the substantial amorphization of the zeolite. Therefore, much more diluted (1 and 2 wt $\% \mathrm{NH}_{4} \mathrm{HF}_{2}$ ) solutions were employed to obtain hierarchical zeolite L. The use of $1 \mathrm{wt} \% \mathrm{NH}_{4} \mathrm{HF}_{2}$ solution did not change the surface characteristics of zeolite substantially, even after treatment at 60 and $80^{\circ} \mathrm{C}$ (Table 1). The 2 wt $\% \mathrm{NH}_{4} \mathrm{HF}_{2}$ solution was used at room temperature from 2 to 60 minutes which provided materials with slightly increased micropore volume.

The chemical composition of the parent and treated samples determined by ICP-AES are presented in Table 1. The parent $\mathrm{NH}_{4}-\mathrm{L}$ has a Si/Al ratio of 3.0, typical for zeolite $\mathrm{L}^{\left[{ }^{[2,25]}\right.}$ This composition is retained after leaching with a $20 \mathrm{wt} \% \mathrm{NH}_{4} \mathrm{~F}$ solution for 3 and $20 \mathrm{~min}$, then slightly increases $(\mathrm{Si} / \mathrm{Al}=3.1)$ after 60 and $360 \mathrm{~min}$ leaching to reach a $\mathrm{Si} / \mathrm{Al}=3.2$ after $480 \mathrm{~min}$. A more substantial dealumination occurs when the temperature is raised to $60{ }^{\circ} \mathrm{C}(\mathrm{Si} / \mathrm{Al}=3.5)$ and $80{ }^{\circ} \mathrm{C}(\mathrm{Si} / \mathrm{Al}=6.8)$, which is coupled with a substantial decrease in the micropore volume. These results are indicative of an amorphization of the L zeolite. 


\section{WILEY-VCH}

Samples leached with a 40 wt $\% \mathrm{NH}_{4} \mathrm{~F}$ solution show a slight increase in the Si content after 20 and 90 min treatments. Substantial dealumination occurs at 60 and $80{ }^{\circ} \mathrm{C}$, as the $\mathrm{Si} / \mathrm{Al}$ ratios raise to 3.8 and 12.7, respectively. No substantial change in framework composition is recorded for L zeolite treated with 1 wt $\% \mathrm{NH}_{4} \mathrm{HF}_{2}$. A slight dealumination ( $\left.\mathrm{Si} / \mathrm{Al}=3.2\right)$ occurs after etching with a 2 wt $\%$ $\mathrm{NH}_{4} \mathrm{HF}_{2}$ for 2 to 10 minutes.

The aluminum coordination of the zeolites, studied by ${ }^{27} \mathrm{Al}$ MAS NMR, is displayed in Figure 4 and Figure S5. All samples are in their $\mathrm{NH}_{4}$-form, without thermal activation prior to the NMR measurement. The ${ }^{27} \mathrm{Al}$ MAS NMR spectra show a unique resonance at $59 \mathrm{ppm}$ corresponding to tetrahedrally coordinated Al (Figure 4). ${ }^{27} \mathrm{Al}$ MAS NMR study indicates that after a mild fluoride etching (20 wt \%), no extraframework Al is generated (Figure 4). However, under more severe etching conditions, at a higher temperature (L-I-60-60), a small amount (ca. 1-5\%) of octahedral Al appears (Figure S5). Increasing the $\mathrm{NH}_{4} \mathrm{~F}$ concentration to $40 \mathrm{wt} \%$ and at $80{ }^{\circ} \mathrm{C}$ impacts substantially the structure, as already indicated by the physisorption analysis and extra framework concentration $\mathrm{Al}$ increases to 54\%. The tetrahedrally coordinated aluminum (59 ppm peak) on L-I60-80 and L-II-60-80 samples decrease sharply, in line with their chemical analysis.

Thermogravimetric (TG) analysis monitors the mass loss upon heating of the parent $\mathrm{NH}_{4}$ - $\mathrm{L}_{\text {zeolite }}$ and its fluoride-etched derivatives (Figure S6). All TG curves show three mass loss steps: $i$ ) 25$200{ }^{\circ} \mathrm{C}$, attributed to the removal of loosely bound water, ii) $200-550{ }^{\circ} \mathrm{C}$ attributed to the ammonia release, iii) $550-700{ }^{\circ} \mathrm{C}$ indicative of dehydroxylation, the results are presented in Table S1. For further discussion of thermogravimetric results, the reader is referred to Supporting Information. The acidity of the parent zeolite and its etched derivatives is studied by in situ infrared (IR) spectroscopy of their -OH stretching vibrations (Figure 5). Full spectra of the parent zeolite L after activation is available in SI, Figure S7. The band at $3746 \mathrm{~cm}^{-1}$ is assigned to Si-OH freely vibrating on the external crystal surface and the mesopore area. The parent zeolite exhibits a low intensity peak at $3730 \mathrm{~cm}^{-1}$, commonly assigned to $\mathrm{Si}-\mathrm{OH}$ in defects. ${ }^{[26]}$ Deconvoluted peaks in the $\mathrm{OH}$ region are shown in Figure S8. The band at $3634 \mathrm{~cm}^{-1}$ is attributed to the acidic bridging hydroxyl 


\section{WILEY-VCH}

$\mathrm{Si}(\mathrm{OH}) \mathrm{Al}$ groups and a broad band centered around $3250 \mathrm{~cm}^{-1}$ to hydroxyl groups located in cancrinite cage. ${ }^{[27,28]}$ IR spectra of pyridine remaining adsorbed after desorption at $150{ }^{\circ} \mathrm{C}$ is used to quantify the Brønsted and Lewis acid sites and the results are presented in Table 2. The concentrations of Brønsted and Lewis acid sites increase with respect to the parent zeolite. Sample L-II-20 exhibits the highest ( $\left.575 \mu \mathrm{mol} \mathrm{g} \mathrm{g}^{-1}\right)$ Brønsted acid site concentration. For the majority of the samples, the concentration of Lewis acid sites does not change substantially with the fluoride etching. This result is in agreement with the ${ }^{27} \mathrm{Al}$ NMR study, which showed that the treatment does not generate extra framework aluminum, except in the cases when the zeolite was partially amorphized. Accessibility index (ACI) is defined as the number of acid sites detected by adsorption of the probe molecules divided by the total amount of acid sites in the zeolite based on the measured aluminum content. ${ }^{[29]}$ The increased concentrations are attributed to better accessibility of pyridine to the active sites, due to the mesopore formation. The accessibility index $\left(\mathrm{ACI}_{\mathrm{Py}}\right)$ of fluoride etched samples is higher with respect to the parent material.

We have further studied the zeolite accessibility by employing the 2,6-di-tert-butylpyridine (dTBPy), a probe larger $(0.80 \mathrm{~nm})$ than zeolite $\mathrm{L}$ channel $(0.71 \mathrm{~nm}) .{ }^{[30]}$ The Brønsted acid site concentration is quantified using its characteristic band at $1530 \mathrm{~cm}^{-1}$, Table 2. The dTBPy ACI $\left(\mathrm{ACI}_{\mathrm{dTBPy}-\mathrm{B}}\right)$ is determined for the parent and its etched derivatives. It is known that a zeolite could adsorb molecular larger that the crystallographic diameter of its channel due to the structure breathing effect and distortion of the molecule. Nevertheless, a very limited amount of dTBPy was adsorbed on the parent zeolite L, showing that it is limited to the pore mouth of zeolite L crystals. Two to three times larger amounts were adsorbed on the treated crystals. Thus, the ACI from 0.02 for the parent zeolite increased to 0.06 for the L-II-90 sample, which we attribute to increase mesopore volume, Table 1.

Dealkylation of TiPBz (1,3,5-triispropylbenzene) highlights the catalytic properties of the external surface of zeolite L; this bulky molecule (kinetic diameter: $0.95 \mathrm{~nm}$ ), does not penetrate its 


\section{WILEY-VCH}

micropores. ${ }^{[31]}$ Initial conversions ( $c a .2$ min time on stream) are representative of the state of the pristine external surface as this model reaction suffers from deactivation.

The initial conversion of TiBPz correlates well with the concentration of external acid sites. The parent zeolite, $\mathrm{NH}_{4}-\mathrm{L}$, shows an initial conversion of $50 \%$ while the etched derivatives are substantially higher, around $80 \%$ conversion (Figure 6). The only exception is the $8 \mathrm{~h}$ etched (L-I480) sample. Sample L-I-60 shows the highest initial conversion (94\%); however, this sample deactivates quickly and after 60 minutes its activity drops below the other samples.

The acidity-activity relationship between the number of Brønsted active sites, and the initial catalytic activity is shown in Figure S9. The plot shows that the etched mesoporous zeolites possess a higher concentration of Brønsted acid sites and thus higher catalytic activity in the conversion of TiBPz, which is a consequence of the improved accessibility. It is worth noting that after $122 \mathrm{~min}$ the conversion on parent zeolite activity decreases to $10 \%$, while for the hierarchical zeolites it ranges between 12 and $25 \%$ depending on the treatment conditions. This feature is probably related to the location and toxicity of carbonaceous deposits, as observed earlier. ${ }^{[32]}$ Thus the hierarchical zeolites prove to be more resistant to deactivation by coke deposition on active sites.

\section{Discussion}

Different dealumination techniques such as steaming, treatment with ammonium hexafluorosilicate and hydrochloric acid have been used to control the zeolite L framework composition and generate secondary porosity. ${ }^{[33]}$ In the case of zeolite L, these techniques are not very efficient and often provoke a structural collapse. The LTL structure is retained after treatment with $\mathrm{SiCl}_{4}$, but pore blockage occurs. ${ }^{[34]}$ Here, we etched zeolite $\mathrm{L}$ with aqueous solutions of $\mathrm{NH}_{4} \mathrm{~F}$ and $\mathrm{NH}_{4} \mathrm{HF}_{2}$, at temperatures between 25 and $80{ }^{\circ} \mathrm{C}$, to obtain hierarchical porous materials. Our previous studies showed that due to its double hydrolysis in water $\mathrm{NH}_{4} \mathrm{~F}$ generates $\mathrm{HF}_{2}^{-}$in equilibrium with other products of the reaction. ${ }^{[21]}$ The use of concentrated $\mathrm{NH}_{4} \mathrm{~F}$ solutions $(20-50 \mathrm{wt} \%)$ allows such species to be continuously generated without reaching a very high concentration of $\mathrm{HF}_{2}{ }^{-}$and thus to better control the etching rate of the zeolite. Using an $\mathrm{NH}_{4} \mathrm{HF}_{2}$ solution provides a high 


\section{WILEY-VCH}

concentration (20-40 wt \%) of $\mathrm{HF}_{2}^{-}$; consequently, such treatment is too aggressive and the zeolite etching is difficult to be controlled. Therefore, $\mathrm{NH}_{4} \mathrm{HF}_{2}$ solutions with lower concentrations (1 and 2 wt \%) are more appropriate to be used for the generation of secondary porosity in zeolites.

Zeolite L etched at room temperature with 20 and 40 wt $\% \mathrm{NH}_{4} \mathrm{~F}$ solutions shows increased X-ray crystallinity and retained micropore volume. Such a treatment generates some mesoporosity, but the mesopore contribution to the total pore volume is limited. A slight decrease in crystallinity and microporosity is observed after 360 - $480 \mathrm{~min}$, but the negative impact is minimal. Greater structural changes are observed when $\mathrm{NH}_{4} \mathrm{~F}$ etching takes place at higher temperatures, $60{ }^{\circ} \mathrm{C}$ and $80{ }^{\circ} \mathrm{C}$ (Table 1$)$.

Etching at room temperature with $1 \mathrm{wt} \% \mathrm{NH}_{4} \mathrm{HF}_{2}$ produces derivatives with high crystallinity up to 120 minutes. Similarly, to the $\mathrm{NH}_{4} \mathrm{~F}$ etching, a decrease in crystallinity occurs at elevated temperature $\left(60^{\circ} \mathrm{C}\right.$ and $\left.80{ }^{\circ} \mathrm{C}\right)$. However, the crystallinity loss is lower compared to etching with 20 and $40 \mathrm{wt} \% \mathrm{NH}_{4} \mathrm{~F}$ solutions. It is worth noting that no preferential dealumination of the zeolite is observed. The chemical analysis highlights that $\mathrm{NH}_{4} \mathrm{HF}_{2}$ etchings are unbiased; a negligible increase in $\mathrm{Si} / \mathrm{Al}$ ratio is most probably due to the dissolution of non-zeolitic alumina rich domains. In addition, the samples prepared with 1 and $2 \mathrm{wt} \% \mathrm{NH}_{4} \mathrm{HF}_{2}$ possess a higher crystallinity than their parent zeolite. A similar effect was already reported by Feng et al. on zeolite $\mathrm{Y} .{ }^{[24]} \mathrm{NH}_{4} \mathrm{~F}$ etching under mild conditions also leads to zeolites with higher crystallinity. We attribute this effect of the removing of low crystalline and defective parts of the zeolite as shown by Qin et al. ${ }^{[35]}$

The zeolites etched at room temperature retain their chemical composition and ${ }^{27}$ Al MAS NMR confirms that there are no changes in the aluminum coordination. The IR spectra of hydroxyl stretching vibrations show that the fluoride treated samples contain more surface hydroxyls and peak deconvolution in the silanol region revealed presence of the peak at $3730 \mathrm{~cm}^{-1}$ assigned to Si$\mathrm{OH}$ in defects even after the treatment. No substantial changes in the intensity of the peak corresponding to the bridged hydroxyls, $\mathrm{Si}(\mathrm{OH}) \mathrm{Al}$, is observed. 


\section{WILEY-VCH}

The concentration of Brønsted and Lewis acid sites is monitored by in-situ IR spectroscopy of adsorbed pyridine. The etched samples show an increased concentration of both, due to their better accessibility by the probe molecule. 2,6-di-tert-butylpyridine (dTBPy) is a molecule of choice to investigate the Brønsted external acidity as its kinetic diameter prevents it to penetrate the micropores. The external acid site concentration is highest for the sample prepared with $40 \mathrm{wt} \%$ $\mathrm{NH}_{4} \mathrm{~F}$.

Dealkylation of $\mathrm{TiPBz}$ (1,3,5-triispropylbenzene) selectively probes the catalytic properties of the external surface of zeolite $\mathrm{L}$ as its kinetic diameter $(0.95 \mathrm{~nm})$, prevents its access to the microporosity. ${ }^{[31]}$ The etching process increases the Brønsted acid site concentration on the external surface leading to a higher conversion compared to the parent zeolite L. Since the external surface the treated zeolites do not increase substantially, we attribute the improved catalytic performances to a partial opening of zeolite channels, namely the extraction of atoms at the pore mouths increasing the accessibility to the active sites. It should also be mentioned that unbiased chemical etching performed by $\mathrm{HF}_{2}^{-}$removes defects and low crystalline parts of the samples.

\section{Conclusion}

A commercial zeolite L sample was etched by aqueous solutions of ammonium fluoride and ammonium bifluoride. The ammonium bifluoride solutions with a concentration higher than $5 \%$ are very aggressive making the dissolution process challenging to be controlled. Lowering the $\mathrm{NH}_{4} \mathrm{HF}_{2}$ concentration slows down the dissolution process and affords better control of the zeolite hierarchization. Etching with 1 and 2 wt $\%$ of $\mathrm{NH}_{4} \mathrm{HF}_{2}$ solutions provides zeolites similar to those obtained with 20 and $40 \mathrm{wt} \% \mathrm{NH}_{4} \mathrm{~F}$ solutions, respectively. Using $\mathrm{NH}_{4} \mathrm{HF}_{2}$ solutions results in a substantial decrease in the amount of fluoride agent required, a welcome feature for practical applications. Another advantage of $\mathrm{NH}_{4} \mathrm{HF}_{2}$ solutions is the efficiently generation of mesopores without causing a collapse of the structure or creating extra framework aluminum. These features of 
$\mathrm{NH}_{4} \mathrm{HF}_{2}$ etching provide zeolites with high catalytic activity, in particular, to convert bulky hydrocarbons.

\section{Experimental Section}

\subsection{Post-synthetic Treatment}

Zeolite $\mathrm{L}$ crystals $(\mathrm{Si} / \mathrm{Al}=3.0)$ are purchased from Tosoh (Japan). The parent material is ionexchanged with a $0.5 \mathrm{M} \mathrm{NH} \mathrm{Nl}_{4}$ solution at $60{ }^{\circ} \mathrm{C}$ for $3 \mathrm{~h}$, and the procedure repeated thrice. The zeolite is then washed thoroughly with double distilled water and dried at $60{ }^{\circ} \mathrm{C}$ overnight. The sample is denoted $\mathrm{NH}_{4}-\mathrm{L}$.

The post-synthetic etchings are performed as follows:

I.) $1 \mathrm{~g}$ of $\mathrm{NH}_{4}-\mathrm{L}$ is dispersed in $20 \mathrm{~g}$ of $20 \mathrm{wt} \%$ (weight percent) $\mathrm{NH}_{4} \mathrm{~F}$ at room temperature and stirred from 3 to 480 minutes. This series of samples is denoted L-I-x, where $\mathrm{x}$ is the treatment time in minutes. Samples L-I-60-60 and L-I-60-80 are treated at 60 and $80{ }^{\circ} \mathrm{C}$, respectively, for $60 \mathrm{~min}$.

II.) $1 \mathrm{~g}$ of $\mathrm{NH}_{4}-\mathrm{L}$ zeolite is dispersed in $20 \mathrm{~g}$ of $40 \mathrm{wt} \% \mathrm{NH}_{4} \mathrm{~F}$ at room temperature and stirred from 20 to 90 minutes. This series of samples is denoted L-II-X , where $\mathrm{x}$ is the treatment time in minutes. Samples L-II-60-60 and L-II-60-80 are treated at 60 and $80{ }^{\circ} \mathrm{C}$, respectively, for $60 \mathrm{~min}$.

III.) $1 \mathrm{~g}$ of $\mathrm{NH}_{4}-\mathrm{L}$ zeolite is dispersed in $20 \mathrm{~g}$ of $1 \mathrm{wt} \% \mathrm{NH}_{4} \mathrm{HF}_{2}$ at room temperature and stirred from 5 to 180 minutes. This series of samples is denoted L-III-x, where $\mathrm{x}$ is the treatment time in minutes. Samples L-III-60-60 and L-III-60-80 are treated at 60 and 80 ${ }^{\circ} \mathrm{C}$, respectively, for $60 \mathrm{~min}$. 


\section{WILEY-VCH}

IV.) $1 \mathrm{~g}$ of $\mathrm{NH}_{4}-\mathrm{L}$ zeolite is dispersed in $20 \mathrm{~g}$ of $2 \mathrm{wt} \% \mathrm{NH}_{4} \mathrm{HF}_{2}$ at room temperature and stirred from 2 to 60 minutes. This series of samples is denoted L-IV-x, where $\mathrm{x}$ is the treatment time in minutes. Sample L- IV-60-60 is treated at $60{ }^{\circ} \mathrm{C}$ for $60 \mathrm{~min}$.

Samples were digested in polypropylene bottles. All products are filtered, thoroughly washed with hot (heated to $90^{\circ} \mathrm{C}$ ) double distilled water, then dried at $60{ }^{\circ} \mathrm{C}$ overnight.

\subsection{Characterization}

The X-ray diffraction (XRD) of powder patterns were recorded using Malvern PANalytical X'Pert PRO Diffractometer with $\mathrm{CuK}_{\alpha}$ radiation $(\lambda=1.5418 \AA, 45 \mathrm{kV}, 40 \mathrm{~mA})$. The patterns were collected over a range of $4-50{ }^{\circ} 2 \theta$ with a time per step of $0.0167^{\circ} \mathrm{s}^{-1}$ using a $1 / 4^{\circ}$ divergence slit. Relative crystallinity values were determined from peak area at 22.608, 24.2457, 25.51576, 27.03146, 27.93889, $29.00841,30.6127,33.68757^{\circ} 2 \theta$ for all samples and the parent zeolite L was used as a reference sample.

Scanning electron microscopy (SEM) was performed by a JEOL JSM-7900F low- voltage high resolution scanning electron microscope (SEM). Before the measurement, the sample was deposited on a sample holder using an isopropyl alcohol-based carbon conductive adhesive (tedpella) tape.

Transmission electron microscopy (TEM) analysis was performed on a JEM-2100F. Prior to the measurement, a diluted colloidal suspension of the sample was sonicated for $5 \mathrm{~min}$ and then dropped on a carbon-film-covered 300-mesh copper electron microscope grids and dried.

The $\mathrm{N}_{2}$ physisorption isotherms were analyzed at $-196{ }^{\circ} \mathrm{C}$ utilizing Micromeritics 3Flex high resolution surface characterization analyzer. About $100 \mathrm{mg}$ of the sample was degassed at $300{ }^{\circ} \mathrm{C}$ under vacuum overnight prior to the analysis. The isotherms were recorded using MicroActiv analysis program for 3Flex. Micropore volume $\left(V_{\text {mic }}\right)$ was evaluated from DFT porosity distribution 
using a model of $\mathrm{N}_{2}$ on oxide surface with cylindrical geometry, and total pore volume ( $\left.V_{\text {tot }}\right)$ was determined by the amount of adsorbed nitrogen at $p / p_{0}=0.98$.

The contents of $\mathrm{Si}$ and $\mathrm{Al}$ were determined with inductively coupled plasma atomic emission spectroscopy (ICP-AES). The samples were digested using aqua regia and HF prior to the analysis. The analysis was performed with OES 5100 VDV ICP from Agilent.

The thermogravimetric analysis (TGA) was carried out in an air atmosphere on a SETSYS-1750 CS Evol instrument (SETARAM). Samples were heated in the air up to $800{ }^{\circ} \mathrm{C}$. Prior to the analysis, the samples were exposed to air with an atmosphere of $70 \%$ humidity.

Solid state NMR measurements were carried out using $4 \mathrm{~mm}$ zirconia rotors. ${ }^{27} \mathrm{Al}$ MAS NMR spectra were measured on a Bruker Avance 500 (magnetic field of $9.4 \mathrm{~T}$ ) spectrometer. All experiments were performed using the spinning speed of $14 \mathrm{kHz}$. The chemical shifts were referenced to $0.1 \mathrm{~m} \mathrm{Al}\left(\mathrm{NO}_{3}\right)_{3}$ aqueous solution.

Prior to the FTIR study, the samples were pressed into self-supporting wafers $\left(2 \mathrm{~cm}^{2}\right)$ and activated in-situ at $450{ }^{\circ} \mathrm{C}$ for 2 hours under vacuum $\left(10^{-6}\right.$ torr). The IR spectra (128 scans) were collected on a NICOLET 6700 fitted with a DTGS detector with a $4 \mathrm{~cm}^{-1}$ optical resolution. Pyridine was used to probe all sites in the zeolite samples; typically a pressure of 1 torr pyridine was introduced in the cell to reach saturation, the wafer then heated twice at $150{ }^{\circ} \mathrm{C}$ for $15 \mathrm{~min}$ to ensure a homogeneous diffusion throughout the sample. Pyridine was then stepwise $\left(50^{\circ} \mathrm{C}\right.$ for $\left.10 \mathrm{~min}\right)$ desorbed in the temperature range of $50-450{ }^{\circ} \mathrm{C}$. Sample weights were normalized to $20 \mathrm{mg}$. Brønsted (B) and Lewis (L) acid site concentrations were quantified using the $1545 \mathrm{~cm}^{-1}$ (B, extinction coefficient:

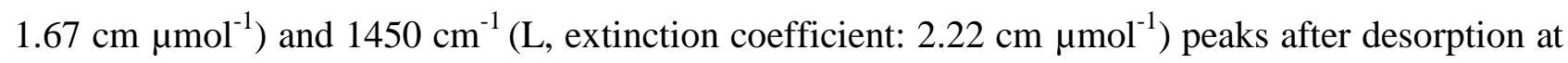
$150{ }^{\circ} \mathrm{C} .{ }^{[36]}$ Deconvolution of the peaks in the $\mathrm{OH}$ region shown in Figure S8 was done in OMNIC 8.3.103 software.

2,6-di-tert-butylpyridine (dTBPy), on the other hand, was used to quantify the external acidity of the zeolites. The same pretreatment procedure was used as that for pyridine adsorption. 0.1 torr of 


\section{WILEY-VCH}

dTBPy was introduced in the cell; then the wafer was heated at $150{ }^{\circ} \mathrm{C}$ for $15 \mathrm{~min}$ two times to ensure a homogeneous diffusion into the samples. The concentration of these Brønsted acid sites was quantified using the dTBPy $1530 \mathrm{~cm}^{-1}$ peak area and an extinction coefficient was calculated according to the procedure outlined by Corma et al. summarized by Equation (1):

$\varepsilon_{\mathrm{dTBPy}}=\frac{\varepsilon_{\mathrm{Py}} \cdot S_{\mathrm{dTBPy}(\mathrm{LTL})}}{S_{\mathrm{Py}(\mathrm{LTL})}}$

with $\varepsilon_{\mathrm{dTBPy}}$ and $\varepsilon_{\mathrm{Py}}$ the integrated molar extinction coefficients for dTBPy and pyridine, respectively, and $S_{\mathrm{dTBP}(\mathrm{LTL})}$ and $S_{\mathrm{Py}(\mathrm{LTL})}$ the integrated band areas of dTBPy and pyridine, respectively, adsorbed on zeolite L. ${ }^{[30,37]}$

The Accessibility Index (ACI) was defined as the number of acid sites detected by a probe molecule divided by the total number of acid sites derived from the aluminum content. Accordingly, the pyridine $\mathrm{ACI}$, is $\mathrm{ACI}_{\mathrm{Py}}=\left(C_{\mathrm{B}}+C_{\mathrm{L}}\right) / \mathrm{Al}_{\mathrm{ICP}}$, as pyridine probes both Brønsted and Lewis acid sites. As dTBPy only probes Brønsted sites, $\mathrm{ACI}_{\mathrm{dTBPy}-\mathrm{B}}$ is the ratio between the Brønsted sites detected by dTBPy and the aluminum content determined by chemical analysis. ${ }^{[29]}$

The dealkylation of 1,3,5-triisopropylbenzene (TiPBz) was performed in a tubular downflow fixedbed reactor operating in the gas phase. A stainless steel reactor (ID $=12.7 \mathrm{~mm}$ ) was successively packed with inert $\mathrm{SiC}$ (particle size 200-300 $\mu \mathrm{m}$ ), $30 \mathrm{mg}$ (W, dried basis) catalyst (particle size $200-500 \mu \mathrm{m})$ and again with $\mathrm{SiC}$, in total $400 \mathrm{mg}$ of $\mathrm{SiC}$, SiC/zeolite ratio 13.3. The catalysts were activated in-situ at $450{ }^{\circ} \mathrm{C}$ for 2 hours under a dry air flow $(50 \mathrm{ml} / \mathrm{min})$ to remove excess water and ammonia, cooled to the reaction temperature $\left(220^{\circ} \mathrm{C}\right)$. A stream of $\mathrm{N}_{2}\left(200 \mathrm{~mL} \cdot \mathrm{min}^{-1}, \mathrm{~F}^{\circ}\right)$ was then diverted to a saturator maintained at $70{ }^{\circ} \mathrm{C}$ filled with $\mathrm{TiPBz}$ and fed to the reactor with a resulting $\mathrm{W} / \mathrm{F}^{\circ}=220 \mathrm{~kg} \cdot \mathrm{mol}^{-1} \cdot \mathrm{s}$. The online analysis of the products was performed with a Varian $\mathrm{CP}-3800$ gas chromatograph fitted with a flame ionization detector (FID), on an HP-Pona capillary column (50m x $0.2 \mathrm{~mm} \times 0.5 \mu \mathrm{m})$.

\section{Supporting Information}




\section{WILEY-VCH}

Supporting Information is available from the Wiley Online Library or from the author.

\section{Acknowledgements}

The authors acknowledge the Normandy region for the Ph.D. grant of Viktoria Babić. V.V. acknoweldeges the financial support from the CARNOT-ESP 3DNANOZET 5281.

Received: ((will be filled in by the editorial staff))

Revised: ((will be filled in by the editorial staff))

Published online: ((will be filled in by the editorial staff)) 


\section{WILEY-VCH}

\section{References}

[1] S. M. Auerbach, K. A. Carrado, P. K. Dutta, Handbook of Zeolite Science and Technology, CRC Press, 2003.

[2] D. W. Breck, N. A. Acara, Crystalline Zeolite L, 1965, US3216789A.

[3] C. Baerlocher, R. M. Barrer, Z. Kristallogr. - Cryst. Mater. 1972, 136, 245.

[4] M. Breysse, J.-R. Bernard (Elf Antar France), Ger. DE3165511D1, 1984.

[5] A. E. Schweizer (ExxonMobil Research and Engineering Co), USA. US4992401A, 1991

[6] F. Di Renzo, F. Fajula, Stud. Surf. Sci. Catal. 2005, 157, 1.

[7] J. M. Newsam, B. G. Silbernagel, A. R. Garcia, M. T. Melchior, S. C. Fung, Stud. Surf. Sci. Catal. 1991, 67, 211

[8] J. C. Bricker, Top Catal 2012, 55, 1309.

[9] H. Pan, G. Wei, H. Yuan, Q. Huo, Q. Li, X. Pan, W. Wang, X. Yu, Stud. Surf. Sci. Catal. 2007, $170,1392$.

[10] P. Huifang, L. Xingyu, W. Guoyou, Y. Hailiang, P. Xinghong, H. Quan, Y. Pingxiang, Pet. Sci. 2007, 4,75 .

[11] Q. Huo, T. Dou, Z. Zhao, H. Pan, Appl. Catal., A, 2010, 381, 101.

[12] Q. Huo, Y. Gong, T. Dou, Z. Zhao, H. Pan, F. Deng, Energy Fuels, 2010, 24 , 3764.

[13] D. P. Serrano, J. Aguado, J. M. Escola, Catalysis, 2011, 23, 253.

[14] R. Li, N. Linares, J. G. Sutjianto, A. Chawla, J. Garcia- Martinez, J. D. Rimer, Angew. Chem., Int. Ed. 2018, 57, 11283.

[15] E. Koohsaryan, M. Anbia, Chin. J. Catal. 2016, 37, 447.

[16] V. Valtchev, S. Mintova, MRS Bull. 2016, 41, 689.

[17] K. Na, C. Jo, J. Kim, K. Cho, J. Jung, Y. Seo, R. J. Messinger, B. F. Chmelka, R. Ryoo, Science 2011, 333, 328.

[18] R. Szostak, in Studies in Surface Science and Catalysis, Vol. 137 (Eds: H. van Bekkum, E. M. Flanigen, P. A. Jacobs, J. C. Jansen), 2001, Ch. 6.

[19] X. Zhang, D. Liu, D. Xu, S. Asahina, K. A. Cychosz, K. V. Agrawal, Y. A. Wahedi, A. Bhan, S. A. Hashimi, O. Terasaki, M. Thommes, M. Tsapatsis, Science 2012, 336, 1684.

[20] K. Zhang, S. Fernandez, J. A. Lawrence, M. L. Ostraat, ACS Omega 2018, 3, 18935.

[21] Z. Qin, L. Lakiss, J.-P. Gilson, K. Thomas, J.-M. Goupil, C. Fernandez, V. Valtchev, Chem. Mater. 2013, 25, 2759.

[22] V. Valtchev, J.-P. Gilson, Z. Qin, (CNRS), Fra. WO2016005783 A1, 2016.

[23] A. Misra, J. Prasad, J. A. Sees, L. H. Hall, USA. US6048406A, 2000.

[24] A. Feng, Y. Yu, L. Mi, Y. Cao, Y. Yu, L. Song, Microporous Mesoporous Mater. 2019, 280, 211.

[25] R. M. Barrer, H. Villiger, Z. Kristallogr. - Cryst. Mater, 1969, 128, 352.

[26] K. A. Tarach, J. Tekla, U. Filek, A. Szymocha, I. Tarach, K. Góra-Marek, Microporous Mesoporous Mater. 2017, 241, 132.

[27] H. G. Karge, E. Geidel, in Characterization I, Springer, Berlin, Heidelberg, 2004.

[28] E. Brunner, K. Beck, M. Koch, L. Heeribout, H. G. Karge, Microporous Mater. 1995, 3, 395.

[29] F. Thibault-Starzyk, I. Stan, S. Abelló, A. Bonilla, K. Thomas, C. Fernandez, J.-P. Gilson, J. Pérez-Ramírez, J. Catal. 2009, 264, 11.

[30] A. Corma, V. Fornés, L. Forni, F. Márquez, J. Martínez-Triguero, D. Moscotti, J. Catal. 1998, $179,451$.

[31] K.-G. Haw, J.-M. Goupil, J.-P. Gilson, N. Nesterenko, D. Minoux, J.-P. Dath, V. Valtchev, New J. Chem. 2016, 40, 4307.

[32] L. Lakiss, F. Ngoye, C. Canaff, S. Laforge, Y. Pouilloux, Z. Qin, M. Tarighi, K. Thomas, V. Valtchev, A. Vicente, L. Pinard, J.-P. Gilson, C. Fernandez, J. Catal. 2015, 328, 165. 


\section{WILEY-VCH}

[33] R. Rachwalik, Z. Olejniczak, M. Hunger, B. Sulikowski, XXXIX Polish Sem. on Nuclear Magnetic Resonance and Its Applications, Kraków, Poland, 2006, 79.

[34] P. Bartl, W. F. Hölderich, Microporous Mesoporous Mater. 2000, 38, 279.

[35] Z. Qin, G. Melinte, J.-P. Gilson, M. Jaber, K. Bozhilov, P. Boullay, S. Mintova, O. Ersen, V. Valtchev, Angew. Chem. 2016, 128, 15273.

[36] C. A. Emeis, J. Catal. 1993, 141, 347.

[37] A. G. Popov, V. S. Pavlov, I. I. Ivanova, J. Catal. 2016, 335, 155.

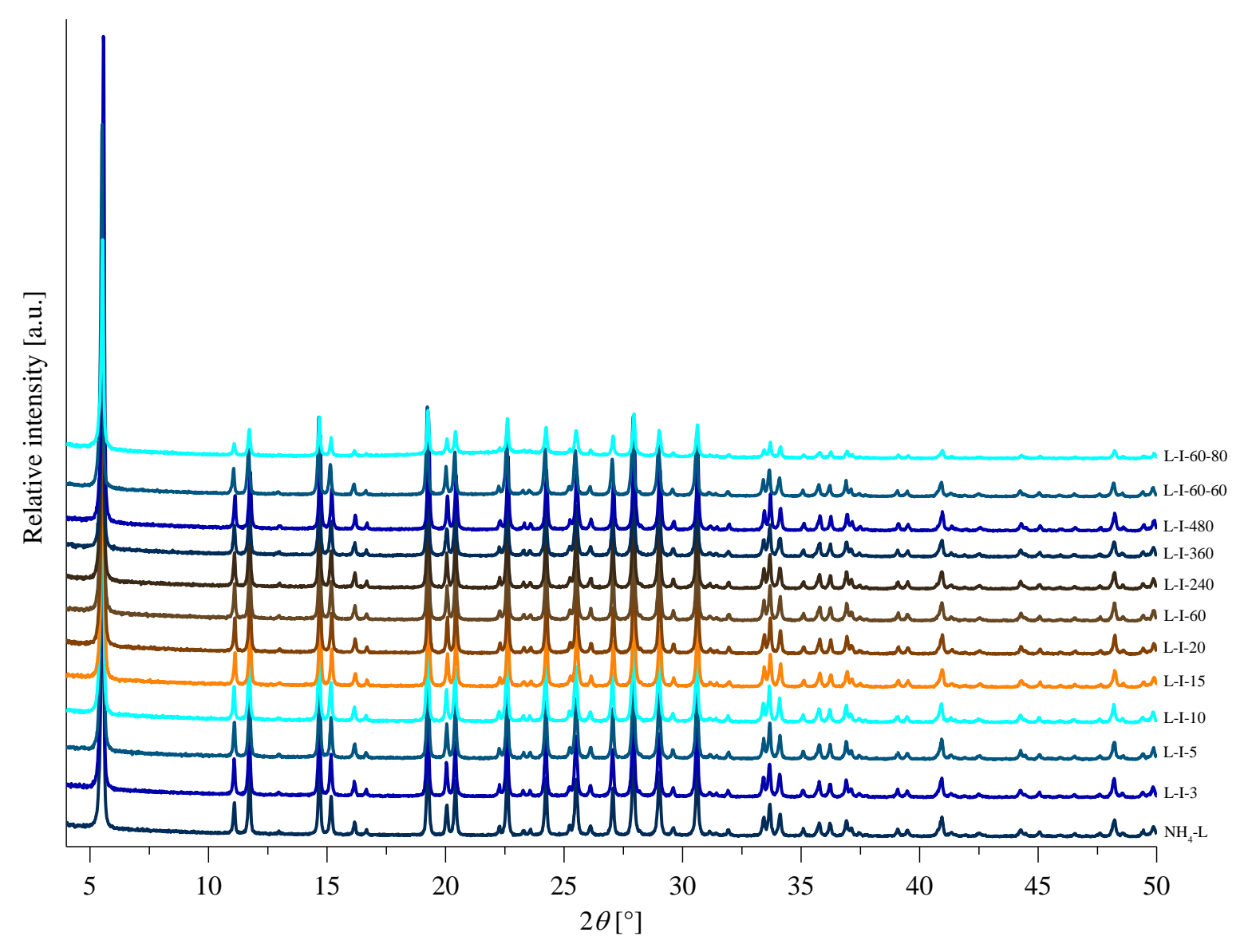

Figure 1. XRD patterns of zeolite L treated with 20 wt $\% \mathrm{NH}_{4} \mathrm{~F}$.
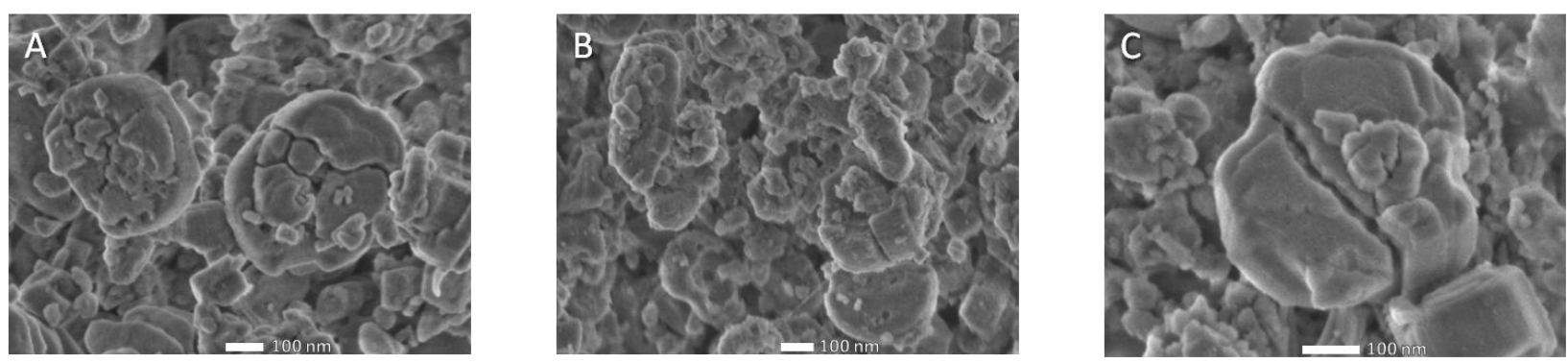

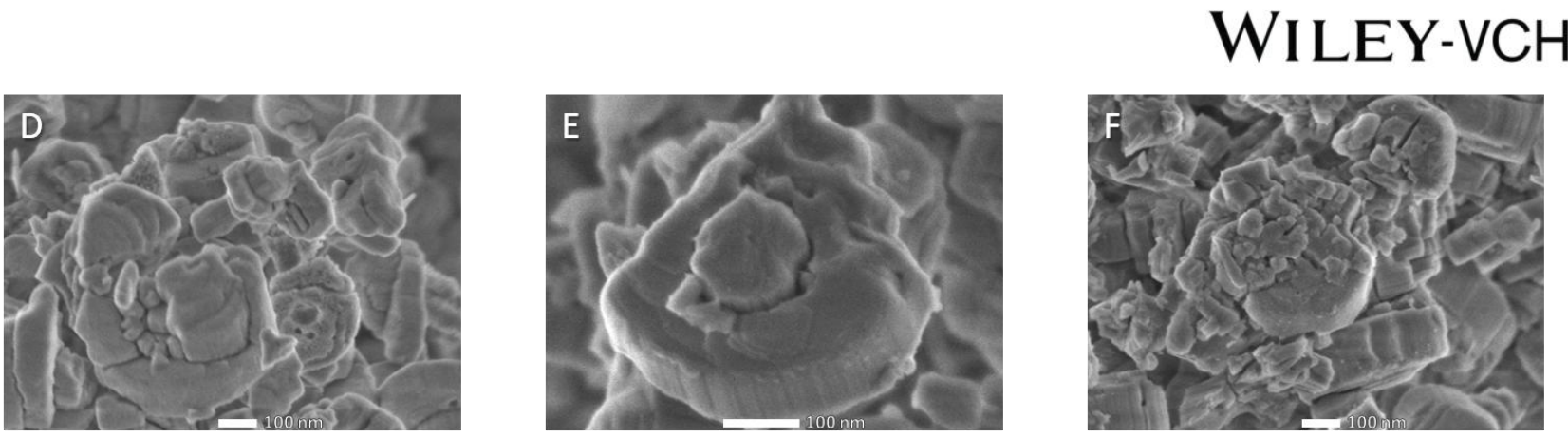

Figure 2. SEM micrographs of L-II-40 (A), L-II-60-60 (B), L-III-40 (C), L-III-180 (D), L-III-60-60 (E), and L-III-60-80 (F) samples.
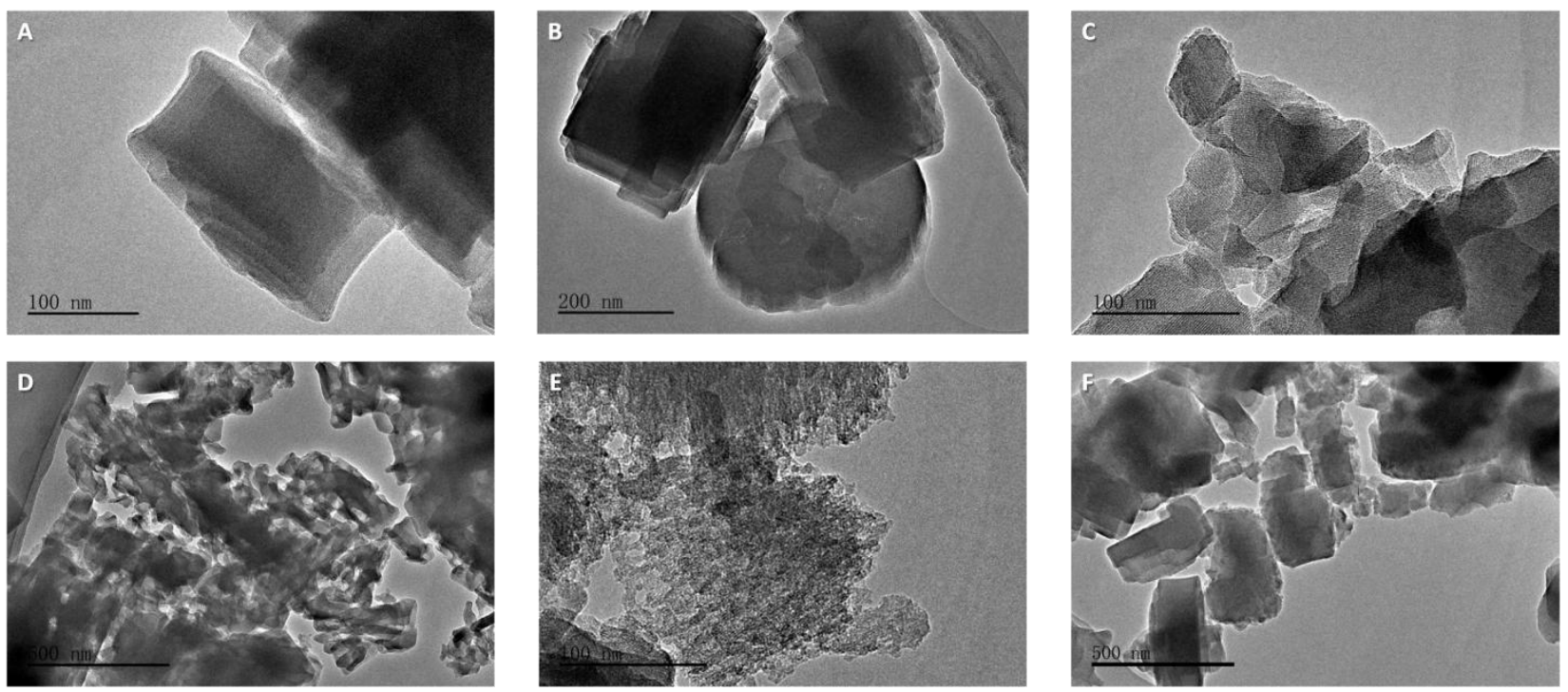

Figure 3. TEM micrographs of $\mathrm{NH}_{4}-\mathrm{L}$ (A), L-I-5 (B), L-I-60 (C), L-III-180 (D), L-III-60-60 (E), and L-III-60-80 (F) samples. 


\section{WILEY-VCH}

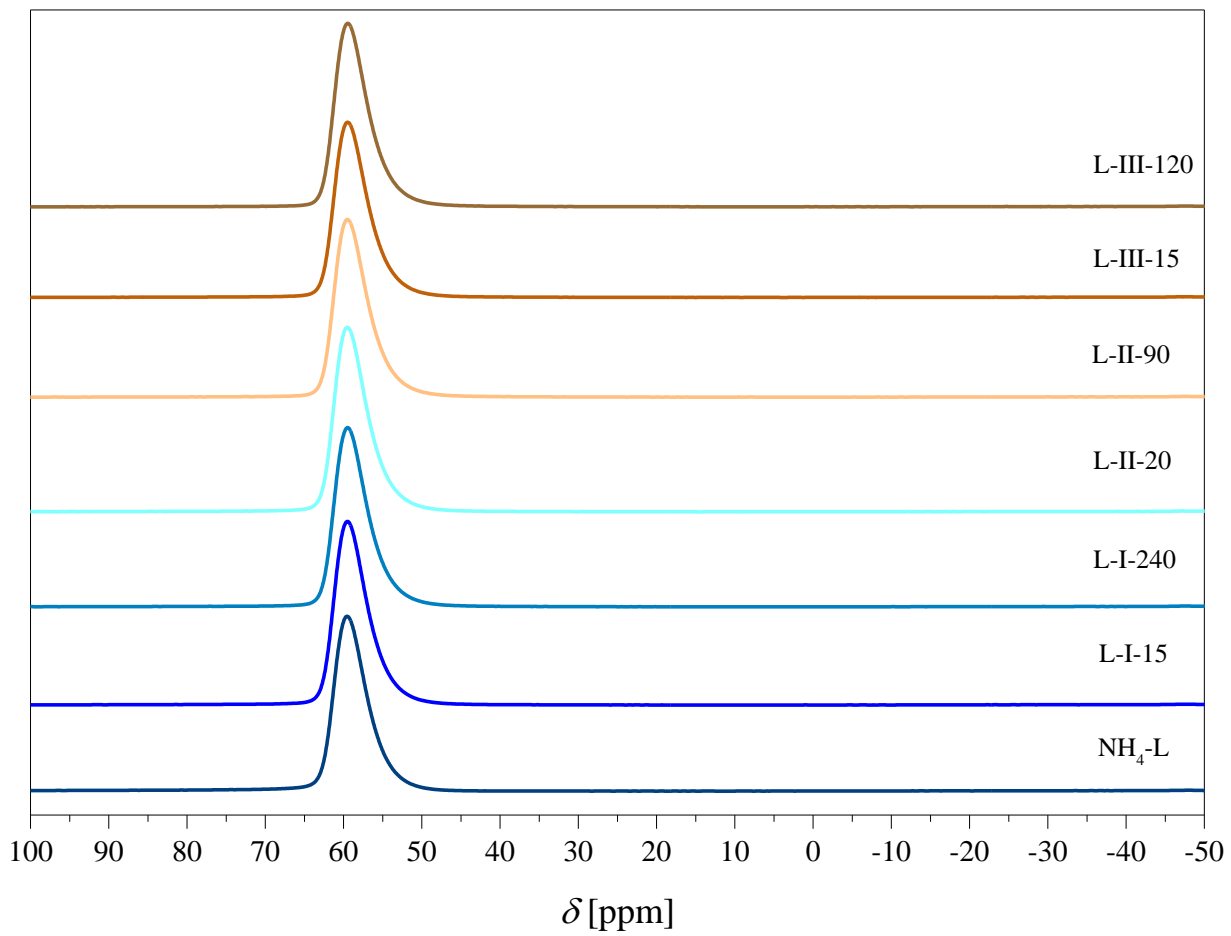

Figure 4. The ${ }^{27} \mathrm{Al}$ MAS NMR of the parent zeolite and derivatives treated at room temperature with 20 (L-I), 40 (L-II) wt $\% \mathrm{NH}_{4} \mathrm{~F}$, and $1.0 \mathrm{wt} \% \mathrm{NH}_{4} \mathrm{HF}_{2}$ (L-III) solutions.

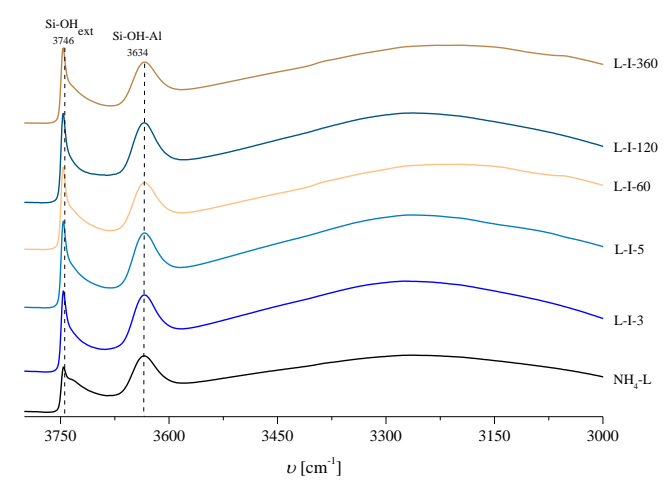

C

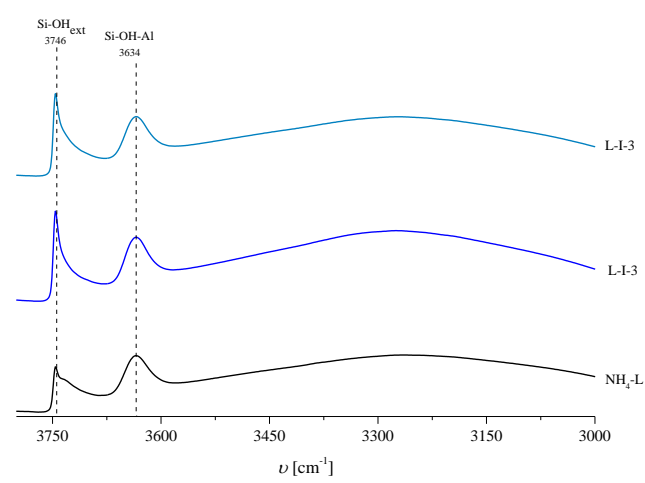

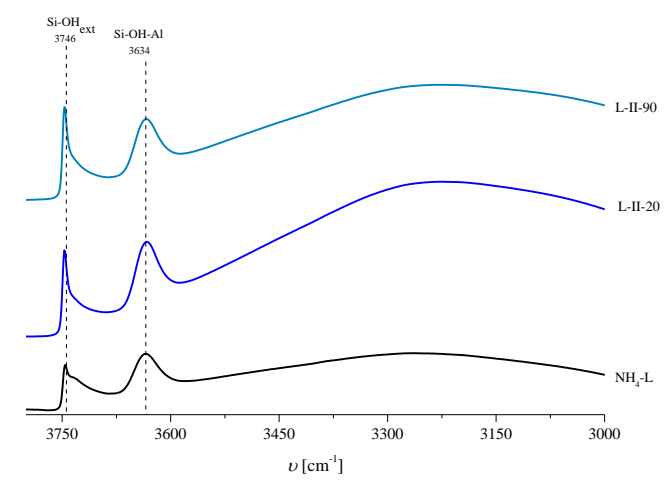

Figure 5. Room temperature IR spectra in the O-H vibrations region for the parent and some etched derivatives: 20 wt $\% \mathrm{NH}_{4} \mathrm{~F}(\mathrm{~A}), 40 \mathrm{wt} \% \mathrm{NH}_{4} \mathrm{~F}(\mathrm{~B}), 1$ wt $\% \mathrm{NH}_{4} \mathrm{HF}_{2}(\mathrm{C})$ solutions. 


\section{WILEY-VCH}
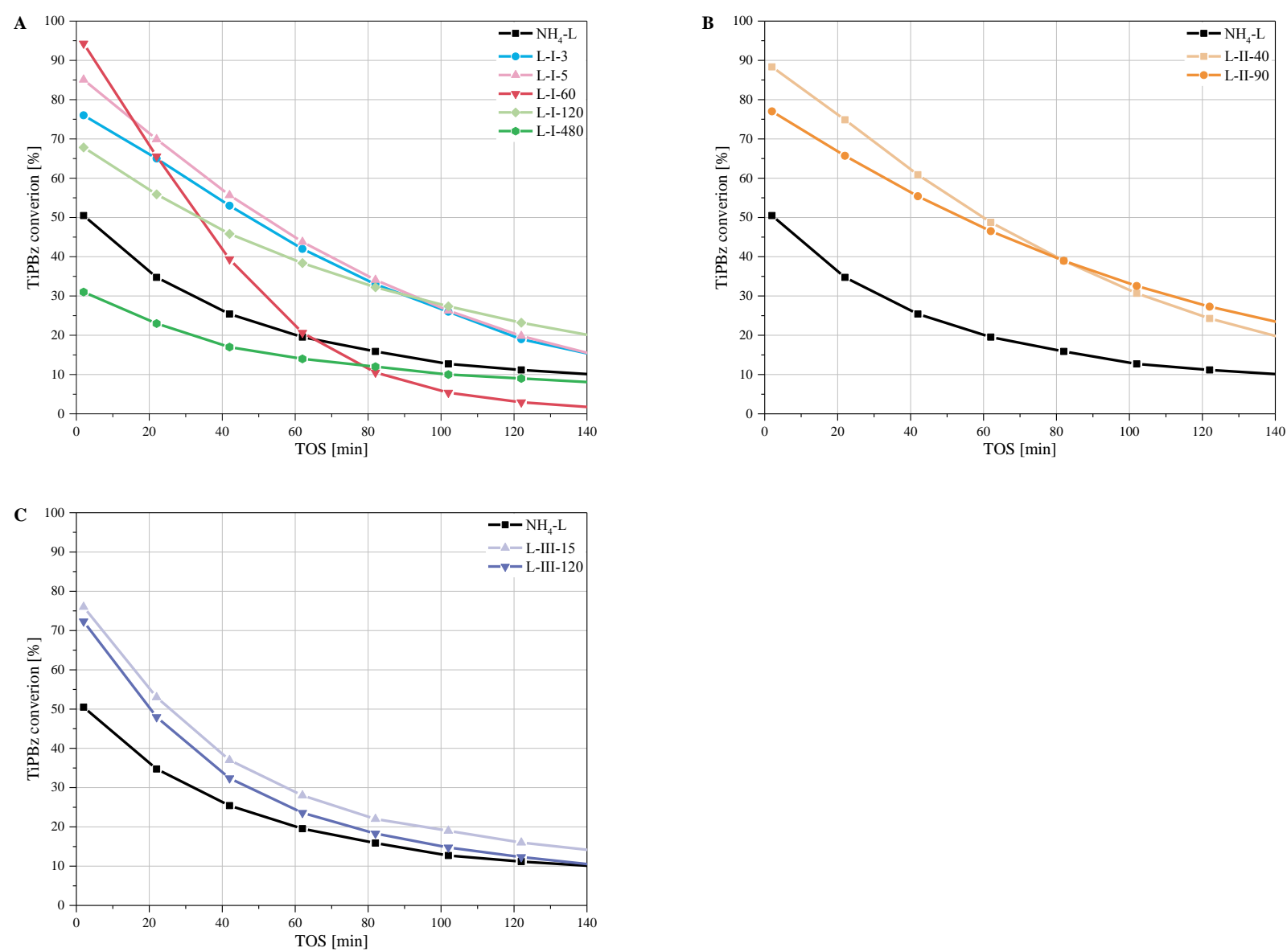

Figure 6. Conversion of 1,3,5-triispropylbenzene (TiPBz) for the parent and some etched derivatives: $20 \mathrm{wt} \% \mathrm{NH}_{4} \mathrm{~F}(\mathrm{~A}), 40 \mathrm{wt} \% \mathrm{NH}_{4} \mathrm{~F}(\mathrm{~B}), 1 \mathrm{wt} \% \mathrm{NH}_{4} \mathrm{HF}_{2}(\mathrm{C})$ solutions. 
Table 1. Chemical composition and textural properties of the parent and treated zeolites.

\begin{tabular}{|c|c|c|c|c|c|}
\hline Sample & $\begin{array}{l}\text { XRD } \\
{[\%]^{\mathrm{a}}}\end{array}$ & $\begin{array}{c}\mathrm{Si} / \mathrm{Al}_{\mathrm{ICP}} \\
{\left[\mathrm{molmol}^{-1}\right]}\end{array}$ & $\begin{array}{c}S_{B E T} \\
{\left[\mathrm{~m}^{2} \mathrm{~g}^{-1}\right]}\end{array}$ & $\begin{array}{c}V_{\text {micro }} \\
{\left[\mathrm{cm}^{3} \mathrm{~g}^{-1}\right]}\end{array}$ & $\begin{array}{c}V_{\text {meso }} \\
{\left[\mathrm{cm}^{3} \mathrm{~g}^{-1}\right]}\end{array}$ \\
\hline $\mathrm{NH}_{4}-\mathrm{L}$ & 100 & 3.0 & 452 & 0.17 & 0.05 \\
\hline L-I-3 & 100 & 3.0 & 453 & 0.17 & 0.07 \\
\hline L-I-5 & 100 & 3.0 & 464 & 0.18 & 0.07 \\
\hline L-I-10 & 100 & 3.0 & 457 & 0.17 & 0.07 \\
\hline L-I-15 & 100 & 3.0 & 454 & 0.17 & 0.08 \\
\hline L-I-20 & 100 & 3.0 & 456 & 0.18 & 0.08 \\
\hline L-I-60 & 100 & 3.1 & 453 & 0.17 & 0.08 \\
\hline L-I-120 & 100 & 3.1 & 456 & 0.17 & 0.08 \\
\hline L-I-240 & 100 & 3.1 & 453 & 0.17 & 0.09 \\
\hline L-I-360 & 94 & 3.1 & 441 & 0.16 & 0.09 \\
\hline L-I-480 & 96 & 3.2 & 441 & 0.16 & 0.09 \\
\hline L-I-60-60 & 79 & 3.5 & 333 & 0.14 & 0.12 \\
\hline L-I-60-80 & 43 & 6.3 & 227 & 0.08 & 0.20 \\
\hline L-II-20 & 103 & 3.1 & 453 & 0.17 & 0.13 \\
\hline L-II-40 & 103 & 3.1 & 464 & 0.18 & 0.13 \\
\hline L-II-90 & 103 & 3.1 & 446 & 0.17 & 0.13 \\
\hline L-II-60-60 & 78 & 3.8 & 397 & 0.15 & 0.19 \\
\hline L-II-60-80 & 18 & 12.7 & 241 & 0.07 & 0.29 \\
\hline L-III-5 & 105 & 3.1 & 461 & 0.17 & 0.07 \\
\hline L-III-10 & 105 & 3.1 & 471 & 0.18 & 0.07 \\
\hline L-III-15 & 105 & 3.1 & 472 & 0.18 & 0.07 \\
\hline L-III-40 & 105 & 3.1 & 462 & 0.17 & 0.07 \\
\hline L-III-120 & 103 & 3.1 & 471 & 0.18 & 0.08 \\
\hline L-III-180 & 90 & 3.1 & 458 & 0.17 & 0.07 \\
\hline L-III-60-60 & 89 & 3.0 & 450 & 0.17 & 0.07 \\
\hline L-III-60-80 & 91 & 3.0 & 443 & 0.17 & 0.08 \\
\hline L-IV-2 & 108 & 3.2 & 462 & 0.18 & 0.08 \\
\hline L-IV-5 & 109 & 3.2 & 471 & 0.18 & 0.08 \\
\hline L-IV-10 & 110 & 3.2 & 458 & 0.17 & 0.09 \\
\hline L-IV-60 & 92 & 3.0 & 375 & 0.17 & 0.07 \\
\hline L-IV-60-60 & 98 & 3.0 & 375 & 0.17 & 0.07 \\
\hline
\end{tabular}




\section{WILEY-VCH}

${ }^{\text {a }}$ Relative crystallinity to the reference sample measured by XRD.

Table 2. Concentrations of Brønsted and Lewis acid sites in the parent $\mathrm{NH}_{4}-\mathrm{L}$ and zeolite $\mathrm{L}$ samples evaluated by in-situ IR spectroscopy of probe molecules.

\begin{tabular}{|c|c|c|c|c|c|c|c|c|}
\hline Sample & $\begin{array}{l}\mathrm{Al}_{\mathrm{ICP}} \\
{\left[\mu \mathrm{mol} \mathrm{g}{ }^{-1}\right]}\end{array}$ & $\begin{array}{l}\text { Py-B }{ }^{\mathrm{a}} \\
{\left[\mu \mathrm{mol} \mathrm{g}{ }^{-1}\right]}\end{array}$ & $\begin{array}{l}\mathrm{Py}-\mathrm{L}^{\mathrm{a}} \\
{\left[\mu \mathrm{mol} \mathrm{g}{ }^{-1}\right]}\end{array}$ & $\begin{array}{l}\mathrm{C}_{\mathrm{B}}+\mathrm{C}_{\mathrm{L}} \\
{\left[\mu \mathrm{mol} \mathrm{g} \mathrm{g}^{-1}\right]}\end{array}$ & $\begin{array}{l}\mathrm{ACI}_{\mathrm{Py}} \\
{[-]}\end{array}$ & $\begin{array}{l}\text { Py-B }{ }^{\mathrm{b}} \\
{\left[\mu \mathrm{mol} \mathrm{g}{ }^{-1}\right]}\end{array}$ & $\begin{array}{l}\text { dTBPy-B }{ }^{\mathrm{c}} \\
{\left[\mu \mathrm{mol} \mathrm{g}{ }^{-1}\right]}\end{array}$ & $\begin{array}{l}\mathrm{ACI}_{\mathrm{dTBPy}-\mathrm{B}} \\
{[-]}\end{array}$ \\
\hline $\mathrm{NH}_{4}-\mathrm{L}$ & 3156 & 412 & 233 & 645 & 0.20 & 113 & 68 & 0.02 \\
\hline L-I-3 & 3156 & 476 & 268 & 744 & 0.24 & 140 & I & I \\
\hline L-I-5 & 3156 & 467 & 315 & 782 & 0.25 & 153 & I & I \\
\hline L-I-60 & 3076 & 476 & 319 & 796 & 0.26 & 127 & 164 & 0.05 \\
\hline L-I-120 & 3076 & 500 & 364 & 865 & 0.28 & 134 & I & I \\
\hline L-I-360 & 3076 & 426 & 299 & 725 & 0.24 & 145 & I & I \\
\hline L-I-480 & 3000 & 435 & 246 & 681 & 0.23 & 78 & I & I \\
\hline L-II-20 & 3076 & 575 & 277 & 852 & 0.28 & 173 & I & I \\
\hline L-II-90 & 3076 & 512 & 317 & 829 & 0.27 & 154 & 175 & 0.06 \\
\hline L-III-15 & 3076 & 430 & 271 & 700 & 0.23 & 141 & 153 & 0.05 \\
\hline L-III-120 & 3076 & 398 & 308 & 706 & 0.23 & 123 & I & I \\
\hline
\end{tabular}

Determined at: ${ }^{\mathrm{a}} 150{ }^{\circ} \mathrm{C},{ }^{\mathrm{b}} 350{ }^{\circ} \mathrm{C},{ }^{\mathrm{c}} 150{ }^{\circ} \mathrm{C}$. 


\section{WILEY-VCH}

A post-synthesis modification method based on $\mathrm{NH}_{4} \mathrm{~F}$ and $\mathrm{NH}_{4} \mathrm{HF}_{2}$ aqueous solutions was used to prepare hierarchical zeolite L. Essential advantage of the method is the retained chemical composition, crystallinity and acidity of the zeolite after the treatment, secondary mesopores are generated that serve as "high ways" for molecule transport and thus decrease the impact of diffusion limitations.

Keyword hierarchical zeolites

Viktoria Babić, Lingxue Tang, Zhengxing Qin, Leila Hafiz, Jean-Pierre Gilson, Valentin Valtchev*

Comparative Study of Zeolite L Etching with Ammonium Fluoride and Ammonium Bifluoride Solutions

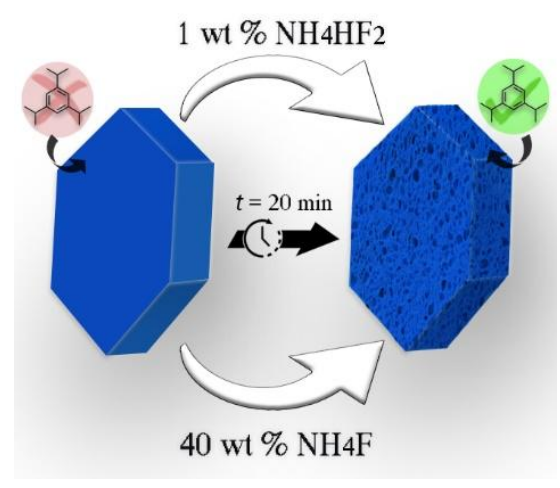

Copyright WILEY-VCH Verlag GmbH \& Co. KGaA, 69469 Weinheim, Germany, 2018. 